九州大学学術情報リポジトリ

Kyushu University Institutional Repository

\title{
EGG AND NYMPHAL PARASITES OF RICE LEAFHOPPERS AND PLANTHOPPERS. A RESULT OF FIELD STUDIES IN
} TAIWAN IN 1979 (PART 1)

Miura, Tadashi

Hirashima, Yoshihiro

Chujo, Michitaka

Chu, Yau-I

https://doi.org/10.5109/2411

出版情報 : ESAKIA. 16，pp.39-50，1981-03. Entomological Laboratory，Faculty of Agriculture， Kyushu University

バージョン：

権利関係 : 


\title{
EGg AND NYMPHAL PARASITES OF RICE LEAFHOPPERS AND PLANTHOPPERS. A RESULT OF FIELD STUDIES IN TAIWAN IN 1979 (PART 1) $^{1) 23)}$
}

\author{
T. Miura, Y. Hirashima, M. T. Chûjô and Yau-I Chu \\ Entomological Laboratory, Faculty of Agriculture, Shimane University, Matsue 690, \\ Japan: Entomological Laboratory, Faculty of Agriculture, Kyushu University, \\ Fukuoka 812, Japan : Hikosan Biological Laboratory, Faculty of Agriculture, \\ Kyushu University, Hikosan, Fukuoka 824-07, Japan: and Department of \\ Entomology and Plant Pathology, National Taiwan \\ University, Taipei, Taiwan
}

\begin{abstract}
Results of field studies on egg parasites of rice leaf- and planthoppers made in Taiwan in 1979 are presented. Anagrus optabilis was reared from the eggs of Sogatella furcifera, Paracentrobia andoi and Anagrus optabilis from Nilaparvata lugens, Anagrus optabilis and Oligosita sp. from Laodelphax striatellus, and Paracentrobia andoi and Gonatocerus sp. from the Nephotettix cincticeps complex. The egg densities of these rice hoppers and the percentage parasitisms of these parasitic wasps are discussed.
\end{abstract}

This paper reports one of the results of our field studies on the natural enemies of rice leafhoppers and planthoppers made in Taiwan from August to November, 1979 (Hirashima,1981). Only the egg parasites of rice leafand planthoppers are dealt with in the present report (Part 1).

Acknowledgement : We are much indebted to the following scientists for their kind assistance and cooperation during the course of our field works in Taiwan: Mr. Ping-shu Yang (楊平世), Lecturer, Department of Entomology and Plant Pathology, National Taiwan University, Taipei; Mrs. Shui-then Chiu (邱 瑞珍), Head, Department of Applied Zoology, Taiwan Agricultural Research

1) Partial result of Grant-in-Aid for Overseas Scientific Survey, No. 404142 (Principal investigator: Y. Hirashima) from the Ministry of Education, Science and Culture.

2) Publication of this paper was financially supported by Grant-in-Aid for Overseas Scientific Survey, No. 504337 (Principal investigator : Y. Hirashima) from the Ministry of Education, Science and Culture.

3) Contribution from the Entomological Laboratory, Faculty of Agriculture, Kyushu University, Fukuoka (Ser. 3, No. 86), and that from the Hikosan Biological Laboratory, Faculty of Agriculture, Kyushu University, Hikosan (Ser. 2, No. 45). 
Institute, Wufeng, Taichung; Dr. Gwo-then Li (李国欽), Director, Plant Protection Center, Wufeng, Taichung ; Mr. Kuang-chi Su (蘇匡基), Director, and Mr. Ching-chung Chen (陳慶忠), Entomologist, Taichung District Agricultural Improvement Station, Taichung; Mr. Ching Huan Cheng (鄭清煥), Entomologist and Chief, Division of Plant Protection, Chiai Agricultural Experiment Station, Chiai; Dr. Yung-song Pan (潘栄松), Head, Department of Plant Protection, Taiwan Sugar Research Institute, Tainan ; Mr. Yi- hsiung Tseng (畺義雄), Section Chief, Tainan Branch Office, Bureau of Commodity Inspection \& Quarantine, Ministry of Economic Affairs, Tainan; Mr. Fu-cheng Yen (顔福成), Entomologist, Tainan District Agricultural Improvement Station, Tainan ; Mr. Hsinchuan Lee (李新伝), Entomologist, Kaohsiung District Agricultural Improvement Station, Pingtung; Mr. Teng-shui Wu (呉登瑞) and Mr. Ching-ho Liu (劉清和), Taitung District Agricultural Improvement Station, Taitung; and Mr. Tsaiwang Tsai (察財旺), Director, Hualien District Agricultural Improvement Station, Hualien.

Acknowledgement is also made to the Ministry of Education, Science and Culture, Japanese Government, for the grants Nos. 404142 and 504337.

\section{Material and Methods}

Egg and nymphal parasites of the rice leaf- and planthoppers were sampled by the following methods.

(1) Method I. Hill cutting

Ten hills of rice were chosen at random in one paddy field. These hills were cut at the water level or just above the soil when there was no water in the field. Number of stalks of each rice hill was used as a crop situation index. Examinations of eggs of rice hoppers were made on these material. It should be noted here that the smaller brown planthopper, Laodelphax striatellus, oviposites not only on stalks but also on leaves (along veins) when its population becomes denser. An egg-mass of rice hoppers was kept in a small glass tube for rearing egg-parasites for two weeks (cf. Miura et al., 1979, p. 23, Fig. 1). It is very probable that the period of two weeks is more than enough to rear the egg parasites at room temperature. The emerged parasites were put in alcohol (75 \%) and brought back to Japan for further examination.

(2) Method II

Method IIA: Sweeping in a paddy field

Sweeping was employed for collecting adults of parasites and their hosts together with other paddy insects and spiders, by using a $42 \times 80 \mathrm{~cm}$ insect net with a handle of $90 \mathrm{~cm}$ in length. Fourty sweeps were made for one unit. Three units of sweepings were made for one paddy field, one at the center and two at the periphery.

Method IIB: Sweeping on the ridge of the paddy field

One unit of sweeping was made in order to collect rice hoppers and their parasites from weeds on the ridge of the paddy field.

AREAS S URVEYE

From August 9 to September 23, 1979, 23 localities were visited and investigations were made for 25 paddy fields, as shown in Fig. 1 and Table 1.

Paddy plants at Taichung, Nantou, Yunlin and many other localities in Chiai Pref. 


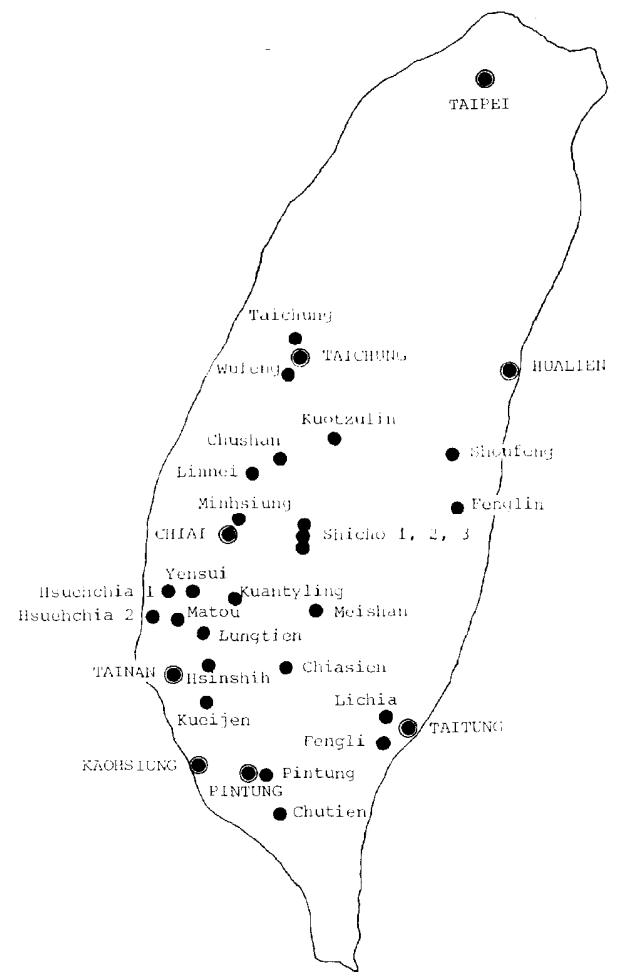

Fig. 1. Map of Taiwan showing the location of areas surveyed.

were in the vegetative stage, while those in Linnei (Yunlin Pref.) were in the flowering stage. Paddy fields (1)-(3) at Shicho (Chiai Pref.) were found at the elevation of 1,400 m. At Taichung District Agricultural Improvement Station, Taichung, surveys were made on the paddy of the japonica variety. In Tainan Pref., paddy was found to be in the flowering (75\%) and ripening (25\%) stages of growth. At Meishan (Kaohsiung Pref.), about $864 \mathrm{~m}$ above the sea level, paddy was in the vegetative stage. Severe damage of paddy by the brown planthopper was noticed in Chutien and Pintung, southern Taiwan. Paddy was found to be in the ripening stage there. In eastern Taiwan, paddy at Taitung and 4 localities in Hualien Pref. was in the vegetative stage,

\section{Results}

\section{EgG PARAsites OF RICE LEAFHopPers AND PLANThoppers}

\section{Egg-density of the hoppers}

Fig. 2 shows the number of eggs of 5 species of rice hoppers per hill of rice collected from 23 localities (25 paddy fields). The figure was calculated from the results of samplings by the method I.

(a) Sugatella furcifera, the white-backed planthopper

Eggs of the white-backed planthopper were collected from 15 localities (15 paddy fields). Total number of egg-masses was 148, and that of individual eggs was 948 . The average number of egg-masses and that of individual eggs per hill of rice was 0.99 and 6.32 , respectively. 
Table 1. Field study areas, dates and sampling methods employed.

\begin{tabular}{|c|c|c|c|c|c|c|c|c|}
\hline Prefecture & Locality & Date & & $\begin{array}{l}\text { Growth } \\
\text { stage } \\
\text { of rice }\end{array}$ & $\begin{array}{l}\text { No. of stems } \\
\text { per hill } \\
\text { of rice }\end{array}$ & $\underset{I}{\text { Samplin }}$ & $\begin{array}{l}n g \\
\bar{A}\end{array}$ & $\frac{\text { method }^{\text {II }}}{\text { B }}$ \\
\hline \multirow[t]{2}{*}{ Taichung } & Taichung & Aug. & 13 & $\mathrm{Re}^{*}$ & 27.2 & $\mathbf{0}$ & $\mathbf{0}$ & $\mathbf{0}$ \\
\hline & Wufeng & & 11 & $\mathrm{Ve}^{*}$ & 25.0 & 0 & 0 & - \\
\hline \multirow[t]{2}{*}{ Nantou } & Kuotzulin & & 19 & $\mathrm{Ve}$ & 18.0 & 0 & 0 & 0 \\
\hline & Chushan & & 22 & $\mathrm{Ve}$ & 24. 6 & 0 & 0 & \\
\hline Yunlin & Linnei & & 27 & $\mathrm{Re}$ & 18.2 & 0 & 0 & 0 \\
\hline \multirow[t]{4}{*}{ Chiai } & Min hsiung & & 25 & $\mathrm{Ve}$ & 18. 2 & $\mathbf{0}$ & 0 & \\
\hline & Shicho (1) & Sep. & & $\mathrm{Ve}$ & 13.4 & 0 & 0 & 0 \\
\hline & Shicho (2) & & 1 & $\mathrm{Ve}$ & 13.3 & 0 & $\mathbf{0}$ & 0 \\
\hline & Shicho (3) & & 1 & $\mathrm{Ve}$ & 13.4 & 0 & 0 & 0 \\
\hline \multirow[t]{8}{*}{ Tainan } & Yensui & & 5 & $\operatorname{Re}$ & 12.8 & 0 & 0 & 0 \\
\hline & Hsuehchia (1) & & 5 & $\operatorname{Re}$ & 22.6 & 0 & 0 & 0 \\
\hline & Hsuehchia (2) & & 11 & Ri* & 13.8 & 0 & 0 & 0 \\
\hline & Matou & Aug. 2 & 26 & $\operatorname{Re}$ & 22.6 & 0 & 0 & - \\
\hline & Kuantyling & & 28 & $\operatorname{Re}$ & 13.6 & 0 & $\mathbf{0}$ & 0 \\
\hline & Lungtien & & 26 & $\operatorname{Re}$ & 17.6 & 0 & 0 & - \\
\hline & Hsinshih & Sep. & 11 & $\mathrm{Ri}$ & 16.4 & $\mathbf{0}$ & 0 & - \\
\hline & Kueijen & & 12 & $\operatorname{Re}$ & 15.4 & 0 & 0 & 0 \\
\hline \multirow[t]{2}{*}{ Kaohsiung } & Meishan & & 8 & $\mathrm{Ve}$ & 14.5 & 0 & $\mathbf{0}$ & 0 \\
\hline & Chiasien & & 10 & $\mathrm{Re}$ & 20.2 & 0 & 0 & 0 \\
\hline \multirow[t]{2}{*}{ Pintung } & Chutien & & 15 & $\mathrm{Ri}$ & 17.2 & 0 & 0 & 0 \\
\hline & Pintung & & 15 & $\mathrm{Ri}$ & 26.8 & 0 & 0 & 0 \\
\hline \multirow[t]{2}{*}{ Taitung } & Fengli & & 19 & $\mathrm{Ve}$ & 12.8 & 0 & 0 & 0 \\
\hline & Lichia & & 19 & $\mathrm{Ve}$ & 22.6 & 0 & 0 & 0 \\
\hline \multirow[t]{2}{*}{ Hualie $n$} & Fenglin & & 22 & $\mathrm{Ve}$ & 18. 2 & 0 & 0 & 0 \\
\hline & Shoufeng & & 22 & $\mathrm{Ve}$ & 18. 1 & 0 & 0 & 0 \\
\hline
\end{tabular}

* Ve: Vegetative stage. Re: Reproductive (or flowering) stage, Ri: Ripening stage.

The densities of eggs of the white-backed planthopper were observed to be high at Kueijen (Tainan Pref.), Hsuehchia (1) (Tainan Pref.), Linnei (Yunlin Pref.) and Fengli (Taitung Pref.), moderate at Matou (Tainan Pref.), Lungtien (Tainan Pref.), Pintung (Pintung Pref.), Lichia (Taitung Pref .), Fenglin (Hualien Pref.) and Shoufeng (Hualien Pref.), and low at Shicho (3) (Chiai Pref.), Yensui (Tainan Pref.), Hsuehchia (2) (Tainan Pref.) and Meishan (Kaohsiung Pref.), while none of egg of this species was found at Taichung (Taichung Pref.), Wufeng (Taichung Pref.), Kuotzulin (Nantou Pref.), Chushan (Nantou Pref.), Minhsiung (Chiai Pref.), Shicho (1) and (2) (Chiai Pref.), Kuantyling (Tainan Pref.), Hsinshih (Tainan Pref.) and Chutien (Pintung Pref.).

(b) Nilaparvatalugens, the brown planthopper

Eggs of the brown planthopper were detected from 11 localities (11 paddy fields). There were 323 egg-masses and 2,573 individual eggs. Thus, the average numbers of egg-masses and individual eggs per hill of rice were 2.94 and 23.39 , respectively.

The densities of eggs of the brown planthopper were found to be high at Hsuehchia (1) and (2), Hsinshih, Kueijen, Meishan and Pintung. moderate at Linnei, Yensui and 
Chiasien (Kaohsiung Pref.), and low at Lungtien and Lichia, while no eggs of this species were found at Taichung, Wufeng, Kuotzulin, Chushan, Minhsiung, Shicho (1), (2) and (3), Matou, Kuantyling, Chutien, Fengli, Fenglin and Shoufeng.

(c) Laodelphaxstriatellus, the smaller brown planthopper

Eggs of the smaller brown planthopper were collected from 15 localities (15 paddy fields). Altogether there were 1,822 egg-masses containing 10,719 individual eggs. Thus, the average numbers of egg-masses and individual eggs per hill of rice were 12.5 and 71.46, respectively.

The densities of eggs of the smaller brown planthopper were found to be high at Taichung, Linnei, Yensui, Hsuehchia (1) and (2), Hsinshih, Kueijen, Meishan, Chiasien, Chutien and Pintung, medium at Shicho (3), Matou and Lichia, and low at Shicho (1). On the other hand, not a single egg was detected at Wufeng, Kuotzulin, Chushan, Minhsi ung, Shicho (2), Kuantyling, Chutien, Fengli, Fenglin and Shoufeng.

(d) Nephotettix spp., the green rice leafhoppers

Three species of Nephotettix, i. e., N. cincticeps (Uhler), N. virescens (Distant) $(=N$. impicticeps Ishihara, 1964) and N. rigropictus(Stål) (=N. apicalis Motschulsky sensu Ishihara, 1964), are found in Taiwan. According to Chen (1972), N. cincticeps commonly occurs throughout Taiwan but N. virescens sparsely occurs in Kaohsiung Pref. (southern Taiwan) and Pintung Pref. (eastern Taiwan) only, while N. nigropictus is found in low density at Taichung, Nantou, Changhua (central Taiwan), Yunlin, Chiai, Tainan, Kaohsiung, Pintung (southern Taiwan), Taitung and Hualien Pref. (eastern Taiwan).

Based on the data presented by Chen (1972), the following fact is made clear.

In 1970, the rate of occurrence of the three species, from June to July (1st cropping of rice) was $88.89 \%$ for cincticeps, $0.31 \%$ for virescens and $10.81 \%$ for nigropictus, while from October to December (2nd cropping) it was $86.13 \%$ for cincticeps, $0.16 \%$ for virescens and $10.81 \%$ for nigropictus.

Table 2. Summary of samplings of eggs of Sogatella furcifera by the method I.

\begin{tabular}{|c|c|c|c|c|c|c|c|c|}
\hline Locality & Date & $\begin{array}{l}\text { No. of egg } \\
\text { masses } \\
\text { found }\end{array}$ & $\begin{array}{l}\text { No. of } \\
\text { eggs } \\
\text { found }\end{array}$ & $\begin{array}{l}\text { Parasite } \\
\text { species }\end{array}$ & $\begin{array}{l}\text { No. of } \\
\text { prtzdt } \\
\text { egg } \\
\text { masses }\end{array}$ & $\begin{array}{c}\% \\
\text { para- } \\
\text { sitism }\end{array}$ & $\begin{array}{l}\text { No. of } \\
\text { prtzd } \\
\text { eggs }\end{array}$ & $\begin{array}{c}\% \\
\text { para- } \\
\text { si tism }\end{array}$ \\
\hline Linnei & Aug. 27 & 16 & 180 & $A "$ & 7 & 43.75 & 48 & 26.67 \\
\hline Shicho(3) & Sep. 1 & 2 & 10 & & $\cdots$ & - & - & - \\
\hline Yensui & Sep. 5 & 2 & 8 & & & - & - & 一 \\
\hline Hsuehchia(1) & Sep. 5 & 17 & 131 & A & 7 & 41.18 & 31 & 23.66 \\
\hline Hsue hchia(2) & Sep. 11 & 1 & 8 & & & - & $\cdots$ & - \\
\hline Matou & Aug. 26 & 5 & 38 & $\mathrm{~A}$ & 5 & 100 & 15 & 39.47 \\
\hline Lungtien & Aug. 26 & 12 & 46 & $\mathrm{~A}$ & 10 & 83.33 & 26 & 56.52 \\
\hline Kueijen & Sep. 12 & 33 & 208 & $\mathrm{~A}$ & 7 & 21.21 & 29 & 13.94 \\
\hline Meishan & Sep. 8 & 1 & 6 & - & - & - & - & - \\
\hline Chiasien & Sep. 10 & 2 & 10 & - & - & - & 一 & - \\
\hline Pintung & Sep. 15 & 4 & 28 & $\mathrm{~A}$ & 4 & 100 & 28 & 100 \\
\hline Fengli & Sep. 19 & 28 & 146 & A & 4 & 14.29 & 11 & 7. 53 \\
\hline Lichia & Sep. 19 & 8 & 45 & & & 一 & - & - \\
\hline Fenglin & Sep. 22 & 5 & 25 & A & 1 & 20.00 & 1 & 4. 00 \\
\hline Shoufeng & Sep. 22 & 12 & 59 & A & 4 & 33.33 & 8 & 13.56 \\
\hline
\end{tabular}

* Anagrus optabilis.

tprtzd $=$ parasitized. 
It is noted from the above record that N.cincticeps is by far common in Taiwan. Eggs of the three rice green leafhoppers are not distinguishable morphologically. The younger nymphs of these species are also very similar to each other, so that no attempt was made to separate them in this study.

We collected the eggs of the green rice leafhoppers from 8 localities ( 8 paddy fields). Total numbers of egg-masses and individual eggs were 44 and 664, respectively. Thus, the average number of egg-masses was calculated to be 0.55 and that of individual eggs was 8.30 per hill of rice. Chen (1978) reported that in August and September the green rice leafhopper becomes fewer in its presence.

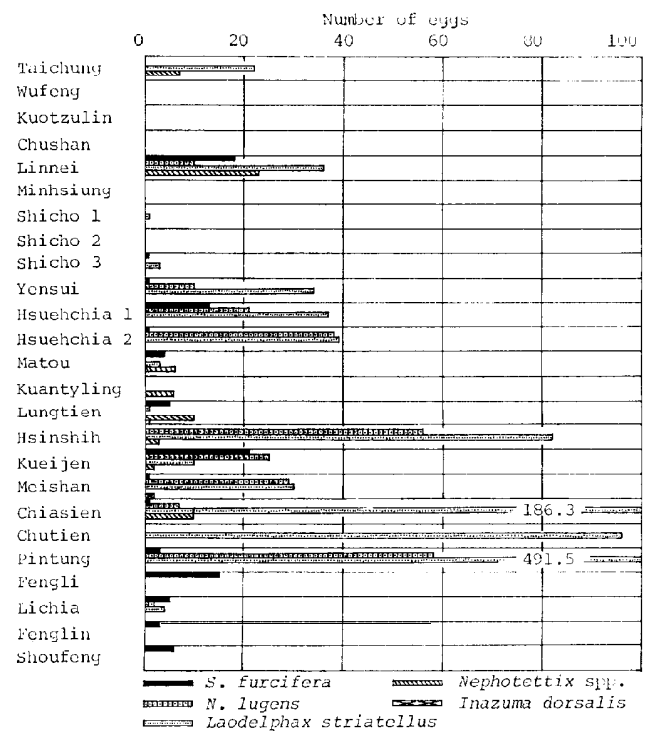

Fig. 2. Number of eggs of rice hoppers per hill of rice plant.

The density of eggs of the green rice leafhoppers was found to be high at Linnei, Lungtien and Chiasien, medium at Taichung, Matou, Kuantyling and Hsinshih, and low at Kueijen, while no eggs were found at Wufeng, Kuotzulin, Chushan, Minhsiung, Shicho (1), (2) and (3), Yensui, Hsuehchia (1) and (2), Meishan, Chutien, Pintung, Fengli, Lichia, Fenglin and Shoufeng.

\section{Egg parasites collected afield}

Egg parasites of rice hoppers ever recorded in Taiwan were listed by Chu and Hirashima (1981). Comprehensive systematic studies on these parasites are necessary not only in Taiwan but also in any other country in Asia including Japan.

We were able to rear four species, Paracentrobia nndoi, Oligosita sp., Anagrus optabilis and Gonatocerus sp., from the eggs of rice hoppers, as mentioned below.

Besides these 4 species many other parasitic wasps belonging to Trichogrammatidae and Mymaridae were collected by the method II but the hosts of them remain to be studied.

\section{Egg parasites of the white-backed planthopper}

Anagrus optabilis (Perkins) was obtained from the eggs of the white-backed planthopper, Sogatella furcifera. According to Yasumatsu et al. (1975) and Miura et al. (1979), 


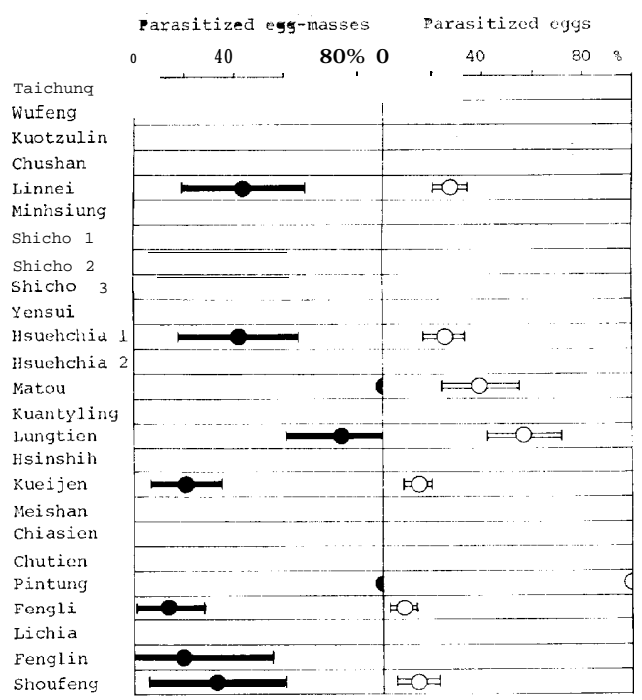

Fig. 3. Percentage parasitism of Anagrus optabilis to Sogatella furcifera (August to September, 1979, Taiwan), with confidence limit at $95 \%$ level.

\begin{abstract}
Anagrus optabilis is one of the most important egg parasites of the white-backed planthopper in Thailand. Table 2 shows the result of our rearing of this species out of the eggs of the hopper collected in the paddy fields from 9 localities. From these figures the percentage parasitism was calculated as follows: the highest one for egg-masses, $100 \%$, was observed at Matou and Pintung, but the lowest, $14.29 \%$, was at Fengli, while the highest one for individual eggs, $100 \%$, was obtained at Pintung but the lowest, $34.00 \%$, was at Fenglin. Accordingly, the mean percentage parasitism of egg-masses was $37.12 \%$ and that of individual eggs was $31.71 \%$, calculated from the total parasitisms obtained from 9 localities. As the egg-masses and individual eggs collected were few in number, the confidence limit at $95 \%$ level was shown in Fig. 3. The percentage parasitism of $A$. optabilis for the individual eggs of the white-backed planthopper was more than $40 \%$ at Matou, Lungtien and Pintung, 20-40\% at Linnei and Hsuehchia (1), and less than $20 \%$ at Kueijen, Fengli, Fenglin and Shouteng.
\end{abstract}

\title{
4. Egg parasites of the brown planthopper
}

Two species of parasitic wasps, Paracentrobia andoi (Ishii) and Anagrus optabilis, were detected from the eggs of the brown planthopper. Esaki et al. (1937) and Ishii (1938) already stated that Paracentrobia andoi parasitizes the brown planthopper. Lin (1974) reported on the natural enemies of the brown planthopper in Taiwan. Otake (1977) dealt with the natural enemies of this hopper. Miura (1976, 77, 78) and Vungsilabutr (1978) provided informations on the biology of Paracentrobia nndoi.

(a) Paracentrobia andoi

Table 3 shows the results of our rearing of Paracentrobia andoi from the eggs of the brown planthopper collected from 7 localities. The highest percentage parasitism of eggmasses was $70.00 \%$ at Chiasien and the lowest was $2.56 \%$ at Hsuehchia (2), while the highest one for individual eggs was $53.6 \%$ at Chiasien and the lowest was $0.71 \%$ at Hsinshih. Thus, the mean percentage parasitism of egg-masses was $30.16 \%$ and that of individual eggs was $23.41 \%$, calculated from the total parasitisms obtained from 7 localities. Fig. 5 shows the relation between parasitized and unparasitized eggs in one egg-mass of 
Table 3. Summary of samplings of eggs of Nilaparvata lugens by the method I.

\begin{tabular}{|c|c|c|c|c|c|c|c|c|c|}
\hline Locality & Date & $\begin{array}{r}\text { No. } \\
\text { n }\end{array}$ & $\begin{array}{l}\text { of egg } \\
\text { nasses } \\
\text { found }\end{array}$ & $\begin{array}{l}\text { No. of } \\
\text { eggs } \\
\text { found }\end{array}$ & $\begin{array}{l}\text { Parasite } \\
\text { species }\end{array}$ & $\begin{array}{l}\text { No. of } \\
\text { prtzd } \\
\text { egg } \\
\text { masses }\end{array}$ & $\begin{array}{c}\% \\
\text { para- } \\
\text { sitism }\end{array}$ & $\begin{array}{c}\text { No. of } \\
\text { prtzd } \\
\text { eggs }\end{array}$ & $\begin{array}{c}\% \\
\text { para- } \\
\text { sitism }\end{array}$ \\
\hline Linnei & $\mathrm{Aug}$ & 27 & 10 & 99 & $A^{*}$ & 2 & 20.00 & & 7. 07 \\
\hline Yensui & Sep. & 5 & 10 & 96 & A & 5 & 50.00 & 33 & 34.38 \\
\hline \multirow[t]{2}{*}{ Hsue hchia (1) } & Sep. & 5 & 23 & 212 & $\mathrm{P}^{*}$ & & 4.35 & & 1.89 \\
\hline & & & & & $\{\mathrm{A}$ & 16 & 69.56 & 93 & 43.87 \\
\hline \multirow[t]{2}{*}{ Hsuehchia (2) } & Sep. & 11 & 39 & 379 & $\int^{P}$ & 1 & 2. 56 & & 1. 58 \\
\hline & & & & & A & 18 & 46.15 & 99 & 26.12 \\
\hline Lungtien & Aug. & 26 & 3 & 12 & A & 1 & 33.33 & 2 & 16.67 \\
\hline \multirow[t]{2}{*}{ Hsinshih } & Sep. & 11 & 69 & 562 & $\int \mathrm{P}$ & 2 & 2.90 & & 0.71 \\
\hline & & & & & A & 13 & 18.84 & 42 & 7. 47 \\
\hline \multirow[t]{2}{*}{ Kueijen } & Sep. & 12 & 36 & 249 & $\int \mathrm{P}$ & 7 & 19.44 & 31 & 12.45 \\
\hline & & & & & $\{\mathrm{A}$ & 16 & 44.44 & 67 & 26.91 \\
\hline \multirow[t]{2}{*}{ Meishan } & Sep. & 8 & 47 & 294 & $\int P$ & 24 & 51.06 & 115 & 39.12 \\
\hline & & & & & $\{\mathrm{A}$ & 3 & 6.38 & & 2. 38 \\
\hline Chiasien & Sep. & 10 & 10 & 69 & $\mathrm{P}$ & 7 & 70.00 & 37 & 53.62 \\
\hline \multirow[t]{2}{*}{ Pintung } & Sep. & 15 & 74 & 582 & $\int^{P}$ & 45 & 60.81 & 317 & 54.47 \\
\hline & & & & & $\{\mathrm{A}$ & 12 & 16.22 & 65 & 11.17 \\
\hline Lichia & Sep. & 19 & 2 & 19 & & - & - & & - \\
\hline
\end{tabular}

* A : Anagrus optabilis. P: Paracentrobia andoi.

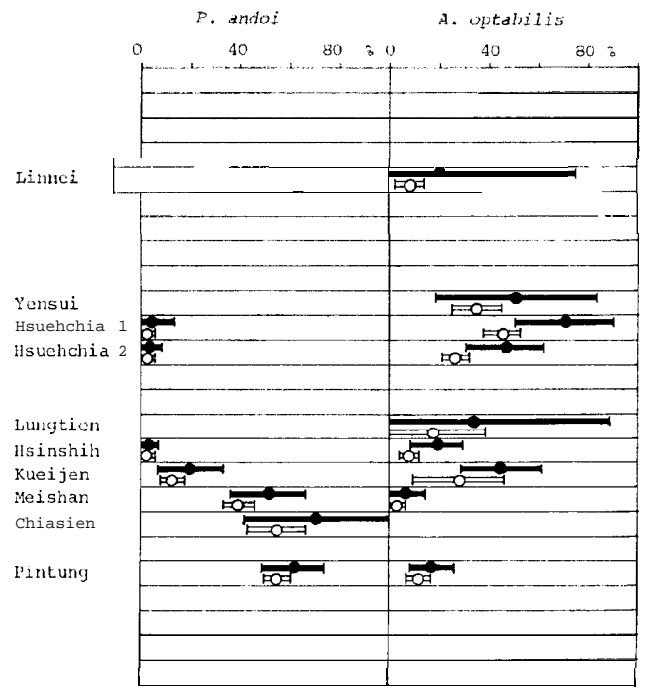

Fig. 4. Percentage parasitism of Paracentrobia andoi and Anagrusoptabilis to Nilaparvata lugens (August to September, 1979, Taiwan). Black circle : parasitized egg-masses, white circle : parasitized eggs, with confidence limit at $95 \%$ level. 


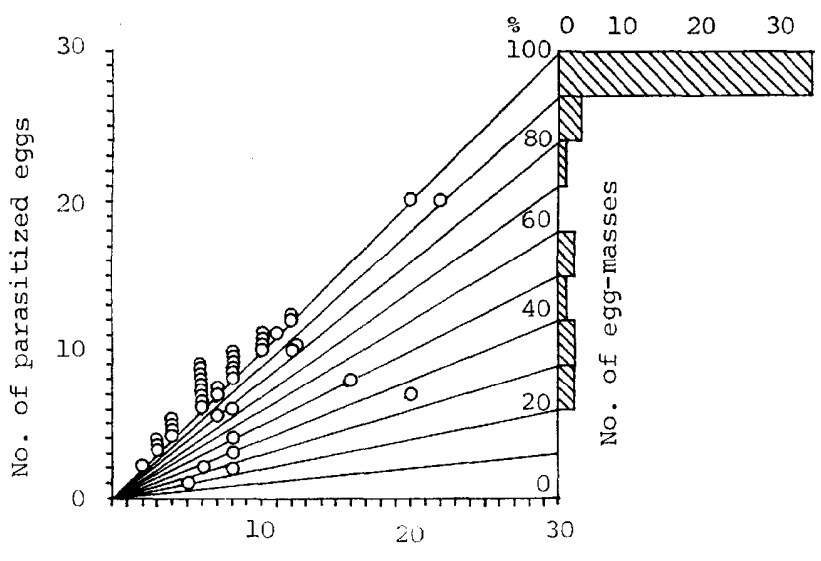

No. of eggs in an egg-mass

Fig. 5. Relation between the parasitized eggs and the number of eggs in an egg-mass of Nilaparvata lugens. Parasite : Paracentrobia andoi. Date : Sep. 15, 1979. Locality: Pintung.

the brown planthopper. It is observed from Fig. 5 that the female of Paracentrobia andoi attacks almost all the eggs when she comes in contact with an egg-mass of the hopper.

\section{(b) Anagrus optabilis}

As shown in Table 3, Anagrus optabilis was reared from the eggs of the brown planthopper collected from 9 localities. The highest percentage parasitism of this wasp for eggmasses of the hopper was $69.56 \%$ at Hsuehchia (1), and the lowest was $6.38 \%$ at Meishan, while the highest percentage parasitism for individual eggs was $43.87 \%$ at Hsuehchia (1) and the lowest was $2.38 \%$ at Meishan, as can be seen in Fig. 4 . Thus, the mean percentage Parasitism was $33.88 \%$ for egg-masses and $19.56 \%$ for individual eggs, calculated from the total percentage parasitisms obtained from 9 localities. The percentage parasitism of Anagrus optabilis for individual eggs of the brown planthopper was more than $40 \%$ at Hsuehchia (1), 20-40\% at Yensui, Hsuehchia (2) and Kueijen, and less than $20 \%$ at Linnei, Lungtien, Hsinshih, Meishan and Pintung.

\section{Egg parasites of the smaller brown planthopper}

Anagrus optabilis and Oligosita sp. were detected as the egg parasites of the smaller brown planthopper.

\section{(a) Anagrus optabilis}

This species was obtained from 14 localities (Table 4). The highest percentage parasitism of Anagrus optabilis to the egg-masses of the smaller brown planthopper was $80.00 \%$ at Matou and the lowest was 20.13\% at Hsinshih, while for individual eggs the highest was $60.00 \%$ at Matou and the lowest was $12.44 \%$ at Hsinshih. The mean percentage parasitism of egg-masses was $45.90 \%$ and that of individual eggs was 30.54 To calculating from the total percentage parasitisms obtained from 14 localities. Fig. 6 shows the confidence limit of the percentage parasitism of A. optabilis at $95 \%$ level. The percentage parasitism of A. optabilis to individual eggs was more than $40 \%$ at Taichung, Yensui, Hsuehchia (1) and Matou, around $30 \%$ at Shicho (3), Hsuehchia (2), Kueijen, Meishan, Chiasien, Chutien and Pintung, and less than $20 \%$ at Linnei, Hsinshih and Lichia. Fig. 7 shows the relation between the parasitized and unparasitized eggs in one egg-mass of the smaller brown planthopper. It is seen from Fig. 7 that the mode of oviposition of A. optablis differs according to the size of the egg-mass. 
Table 4. Summary of sampl ngs of eggs of Laodelphax striatellus by the method I.

\begin{tabular}{|c|c|c|c|c|c|c|c|c|}
\hline Locality & Date & $\begin{array}{c}\text { No. of egg } \\
\text { masses } \\
\text { found }\end{array}$ & $\begin{array}{c}\text { No. of } \\
\text { eggs } \\
\text { found }\end{array}$ & $\begin{array}{r}\text { Parasite } \\
\text { species }\end{array}$ & $\begin{array}{c}\text { No. of } \\
\text { prtzd } \\
\text { egg } \\
\text { masses }\end{array}$ & $\begin{array}{c}\% \\
\text { para- } \\
\text { sitism }\end{array}$ & $\begin{array}{l}\text { No. of } \\
\text { prtzd } \\
\text { eggs }\end{array}$ & $\begin{array}{c}\% \\
\text { para- } \\
\text { sitism }\end{array}$ \\
\hline Taichung & Aug. 13 & 29 & 218 & $A "$ & 21 & 72.41 & 94 & 43.12 \\
\hline \multirow[t]{2}{*}{ Linnei } & Aug. 27 & 70 & 358 & $\int 0 "$ & 2 & 2. 86 & 5 & 1.40 \\
\hline & & & & $l_{A}$ & 20 & 28.57 & 62 & 17.32 \\
\hline Shicho(1) & Sep. 1 & 1 & 3 & & - & - & - & - \\
\hline Shicho(2) & Sep. 1 & 5 & 25 & A & 3 & 60.00 & 6 & 24. OC \\
\hline Yensui & Sep. 5 & 51 & 336 & A & 31 & 60.78 & 147 & 43.75 \\
\hline Hsuehchia(1) & Sep. 5 & 80 & 373 & A & 50 & 62.50 & 174 & 46.65 \\
\hline Hsuehchia(2) & Sep. 11 & 82 & 389 & A & 31 & 37.80 & 140 & 35.99 \\
\hline Matou & Aug. 26 & 5 & 25 & A & & 80.00 & 15 & 60.00 \\
\hline Hsinshih & Sep. 11 & 154 & 820 & A & 31 & 20.13 & 102 & 12.44 \\
\hline Kueijen & Sep. 12 & 23 & 101 & A & 7 & 30.43 & 27 & 26.73 \\
\hline Meishan & Sep. 8 & 73 & 295 & A & 30 & 41.09 & 70 & 23.73 \\
\hline Chiasien & Sep. 10 & 386 & 1863 & A & 131 & 33.94 & 502 & 26.95 \\
\hline Chutien & Sep. 15 & 120 & 963 & A & 60 & 50.00 & 241 & 25.03 \\
\hline \multirow[t]{2}{*}{ Pintung } & Sep. 15 & 736 & 4915 & $\int 0$ & 13 & 17.66 & 63 & 1.28 \\
\hline & & & & la & 268 & 36.41 & 1356 & 27.59 \\
\hline Lichia & Sep. 19 & 7 & 35 & A. & 2 & 28.57 & 5 & 14.29 \\
\hline
\end{tabular}

* A : Anagrus optabilis. 0 Oligosita sp.

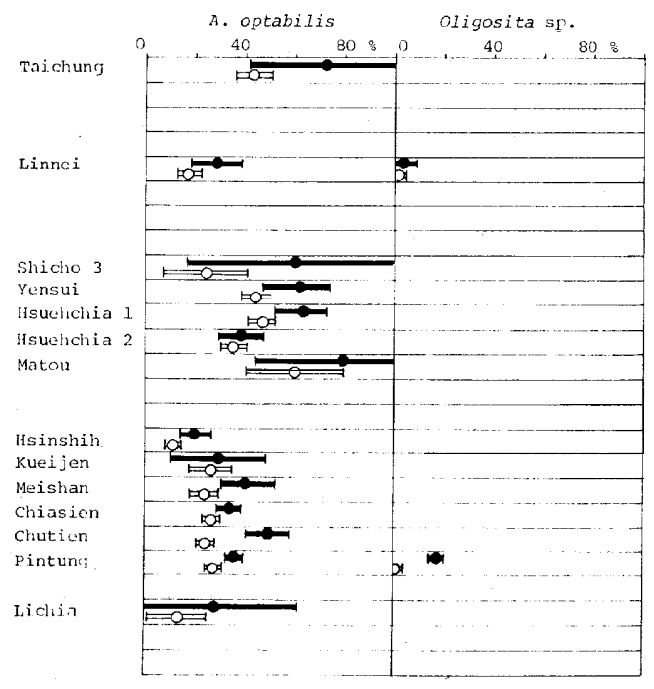

Fig. 6. Percentage parasitism of Anagrusoptabilis and Oligosita sp. to Laodelphax striatellus (August to September, 1979, Taiwan). Black circle : parasitized eggmasses, white circle: parasitized eggs, with confidence limit at $95 \%$ level. 
(b) Oligosita sp.

This species was only detected in few numbers from 2 localities, Linnei and Pingtung.

6. Egg parasites of the green rice leafhoppers

Two species of egg parasites, Paracentrobia andoi and Gonatocerus sp., were detected from the green rice leafhoppers.

Table 5. Summary of samplings of eggs of the Nephotettixcincticeps-complex by the method I.

\begin{tabular}{|c|c|c|c|c|c|c|c|c|}
\hline Locality & Date & $\begin{array}{c}\text { No. of egg } \\
\text { masses } \\
\text { found }\end{array}$ & $\begin{array}{l}\text { No. of } \\
\text { eggs } \\
\text { found }\end{array}$ & $\begin{array}{c}\text { Parasite } \\
\text { species }\end{array}$ & $\begin{array}{c}\text { No. of } \\
\text { prtzd } \\
\text { egg } \\
\text { masses }\end{array}$ & $\begin{array}{l}\% \\
\text { para- } \\
\text { sitism }\end{array}$ & $\begin{array}{l}\text { No. of } \\
\text { prtzd } \\
\text { eggs }\end{array}$ & $\begin{array}{c}\% \\
\text { para- } \\
\text { sitism }\end{array}$ \\
\hline Taichung & Aug. 13 & 6 & 69 & $\mathrm{P}^{*}$ & 4 & 66.67 & 42 & 60.87 \\
\hline \multirow[t]{4}{*}{ Linnei } & Aug. 27 & 15 & 227 & $\{\mathrm{P}$ & 9 & 60.00 & 99 & 43.61 \\
\hline & & & & $6 \mathrm{G}^{*}$ & 3 & 20.00 & 34 & 14.98 \\
\hline & Aug. 26 & 4 & 56 & $\{\mathrm{P}$ & 1 & 25.00 & 8 & 14.29 \\
\hline & & & & lG & 3 & 75.00 & 34 & 60.71 \\
\hline Kuantyling & Aug. 28 & 3 & 60 & $G$ & 2 & 66.67 & 34 & 56.67 \\
\hline \multirow[t]{2}{*}{ Lungtien } & Aug. 26 & 7 & 101 & $\int P$ & 3 & 42.86 & 37 & 36.63 \\
\hline & & & & G & 2 & 28.57 & 32 & 31.68 \\
\hline Hsinshih & Sep. 11 & 2 & 31 & G & 1 & 50.00 & 16 & 51.61 \\
\hline Kueijen & Sep. 12 & 1 & 18 & G & 1 & 100 & 18 & 100 \\
\hline \multirow[t]{2}{*}{ Chiasien } & Sep. 10 & 6 & 102 & $\int P$ & 2 & 33.33 & 20 & 19.61 \\
\hline & & & & G & 3 & 50.00 & 21 & 20.59 \\
\hline
\end{tabular}

* P : Paracentrobia andoi. $\quad G$ : Gonatscerus sp.

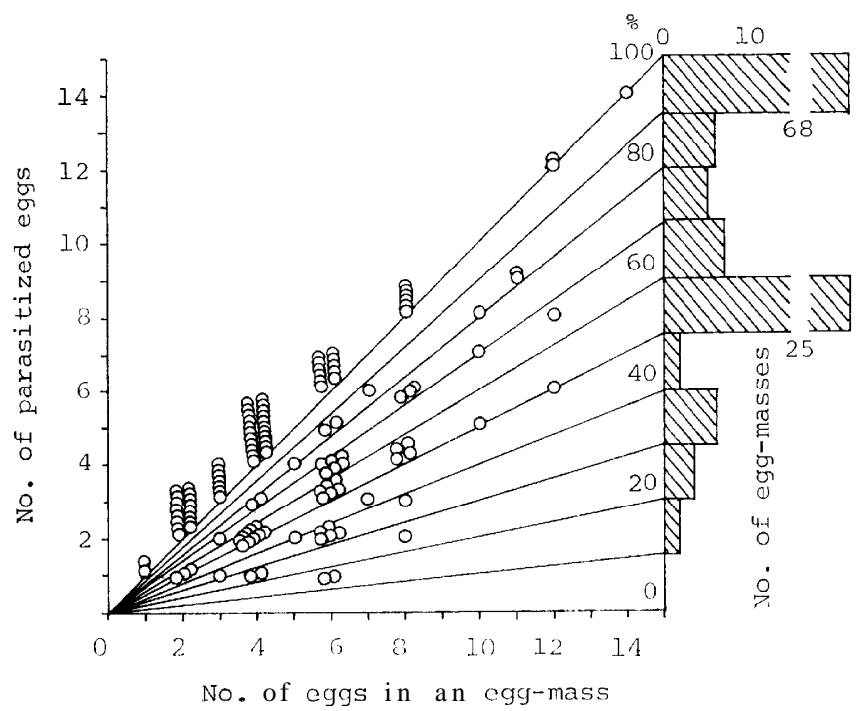

Fig. 7. Relation between the parasitized eggs and the number of eggs in an egg-mass of Laodelphax striatellus. Parasite: Anagrus optabilis. Date: Sept. 10, 1979. Locality: Chiasien. 


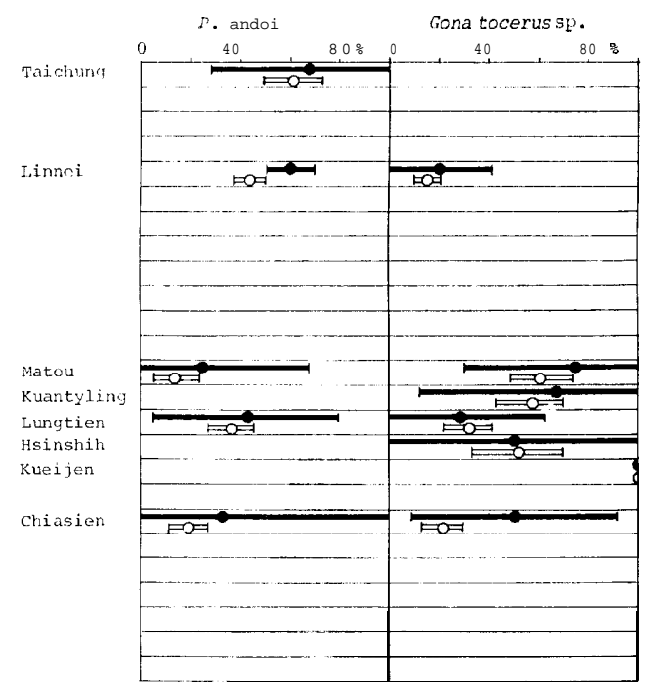

Fig. 8. Percentage parasitism of Paracentrobia andoi and Gonatocerus sp. to the Nephotettix cincticeps-complex (August to September, 1979, Taiwan). Black circle : parasitized eggmasses, white circle : parasitized eggs, with confidence limit at $95 \%$ level.

\section{(a) Paracentrobia andoi}

The parasitic habits of $P$. andoi has already been reported by Lin (1974) in Taiwan and by Orita $(\mathbf{1 9 7 2})$ and Miura $(\mathbf{1 9 7 6}, \mathbf{7 7}, \mathbf{7 8})$ in Japan. Table 5 shows the result of our collecting of $P$. andoi from 5 localities. The percentage parasitism of $P$. andoi to egg-masses was highest $(66.67 \%)$ at Taichung, and lowest $(25.00 \%)$ at Matou, while for individual eggs it was highest $(60.87 \%)$ at Taichung and lowest $(14.29 \%)$ at Matou. Calculating from the results obtained from 5 localities the means of the percentage parasitisms of egg-masses and individual eggs were $45.57 \%$ and $35.00 \%$, respectively. Fig. 8 shows the confidence limit of the percentage parasitism of $P$. andoi at $95 \%$ level. The percentage parasitism of $P$. andoi to individual eggs was more than 40 \% at Taichung and Linnei, 20$40 \%$ at Lungtien and Chiasien, and less than $20 \%$ at Matou.

(b) Gonatocerus sp.

This species was reared from the eggs of the green rice leafhoppers collected from 7 localities, as shown in Table 5. The percentage parasitism of egg-masses was highest $(100 \%)$ at Kueijen and lowest $(20.00 \%)$ at Linnei, while that of individual eggs was highest $(100 \%)$ at Kueijen and lowest $(14.98 \%)$ at Linnei. The means of the percentage parasitism, as calculated from the results obtained from 7 localities, were $55.75 \%$ and $48.03 \%$ for egg-masses and individual eggs, respectively. The confidence limit of the parasitism of Gonatocerus sp. at $95 \%$ level was shown in Fig. 8. The percentage parasitism of Gonatocerus sp. to individual eggs of the green rice leafhopper was more than $50 \%$ at Matou, Kuantyling, Hsinshih and Kueijen, $30 \%$ or so at Lungtien, and less than 20 at I.innei and Chiasien. 